\title{
CULTURE AND PEDAGOGY
}

Kristine Swenson

A Review of Between Borders: Pedagogy and the Politics of Cultural Studies. Eds. Henry A. Giroux and Peter McLaren (Routledge 1994)

As far as the pragmatic level of cultural studies, it's working...In two year colleges, and undergraduate colleges generally I think it's becoming less and less viable to try and separate out the study of high culture because of the people who go to those colleges and of what they'll be doing afterwards; they have to be prepared for a different sort of reality...But within the elite institutions, I definitely think that those of us who do it have an oppositional role...

Jean Franco, 1993 interview $^{1}$

Jean Franco's assessment of the current state of cultural studies in the academy gives some sense of the gap between "undergraduate colleges" and "elite institutions," between practice and theory, which a cultural studies pedagogy must try to bridge before it can hope to "transform the humanities" (Mathews 156). Between Borders: Pedagogy and the Politics of Cultural Studies is an admirable attempt to consider what Lawrence Grossberg describes in his introduction as the "space which extends from the pedagogy of culture to the culture of pedagogy" (11). But this collection is itself an illustration of the difficulty of occupyingperhaps even defining - that space. The fourteen essays, written by important "cultural workers" (critics) such as Chandra Mohanty, bell hooks, Roger Simon, and Abdul R. JanMohamed, are organized rather too loosely around the topics of representation, audience and desire, multiculturalism, and nationalism. Many of the essays appeared first in other contexts which makes for an unevenness of purpose. For instance, Michael Dyson's persuasive reading of Michael Jordan as a "cultural pedagogue" is grouped with Carol Becker's reflections on educating young artists in the midst of hostility toward the NEA, and Nancy Fraser's critique of Habermas follows Ava Collins' study of ideology and intertextuality in 
"thirtysomething." Of course, one could argue that such unevenness is an effect, even a virtue, of cultural studies in general. And much like those of other cultural studies anthologies, these essays share the basic ideologically radical assumptions one expects (i.e., a commitment to non-canonical and popular texts, multiculturalism, difference, and progressive politics) while taking on a surprising array of topics and critical methods. Unfortunately, what tends to get lost in this revelry of diversity is practical pedagogy - the what, how, and why of teaching - the very thing that most of the essays claim to address.

One of the editors, Henry Giroux, is himself a guru of the critical intersection of pedagogy and cultural studies: his Border Crossings: Cultural Workers and the Politics of Education (Routledge, 1992) is not only implied in the title of Between Borders but is cited repeatedly throughout the collection. Appropriately, then, Giroux's essay, "Living Dangerously: Identity Politics and the New Cultural Racism," provides a sort of road map for the rest of the collection and, at the same time, has the virtue of truly investigating an integrated "relationship between education and cultural studies" (Grossberg 1). Because Giroux's essay does unify the collection, I will focus on his essay, tying in other pieces as they relate to his particular concerns.

"Living Dangerously" takes up the struggle between the Left and the New Right over representations of difference (and, more specifically here, with color and "whiteness") that have emerged within our increasingly hybridized culture. Giroux's concern with the New Right's growing influence over these representations in American culture is echoed throughout the collection. Chandra Mohanty's essay, for example, discusses the influence of the New Right in relation to affirmative action and abortion rights legislation, and Simon Watney's "School's Out" addresses conservative objections to teaching about homosexuality in British and American schools. In "Living Dangerously" Giroux provides a reading of the film Grand Canyon to illustrate Hollywood's participation in constructing the "new racism" wherein "cultural differences dissolve into a regime of representations that universalize harmonizing systems while eliminating the discourse of power, conflict, and struggle" (47). In the film, as in the new racism of American culture, whiteness remains uninvestigated while difference is erased (subsumed by white maleness) in the interests of social harmony. Thus, Giroux argues, white liberalism, or "new age whiteness," becomes the panacea of race, class, and gender conflict (40).

This critique helps Giroux to define his notion of a "critical pedagogy of representation" which "focuses on demystifying the act and process of representation" and so allows students to deconstruct the "notion that images, sounds, and texts merely express reality" (47). Giroux's pedagogy of representation relies upon central tenets of the larger project of cultural studies: the "historically contingent" and culturally limited production of representations, and how attention to audience and reception reveals representations that work as "desiring machines" which "secure particular forms of affective investment" (49). As suggested by Jean Franco's above comment, I suspect that many educators of undergraduates have reached through practice the conclusions that Giroux is drawing 
about the potential relationship between cultural studies and pedagogy. Still, by articulating these in the more precise language of theory he reminds us of the care with which we need to take up issues of representation in the classroom. One advantage of the disparateness of the essays in Between Borders is that they mirror the sorts of unexpected and even volatile juxtapositions one encounters when space is made in curricula for mass culture and for the "everyday." They remind us that we can't talk idly about issues as important as race or as seemingly innocuous as "thirtysomething."

The essays on nationalism and multiculturalism in Between Borders speak most directly to Giroux's concern with the historical contingency of representations. Chandra Mohanty's excellent essay, "On Race and Voice," for instance, looks at academic administrator's management of race through the individualization of difference, a concept that complements Giroux's attention to the erasure of differences among groups (Mohanty 151). And, like Giroux who is concerned with the influence of Hollywood, David Trend investigates whether "national identity is a product of media" (225). The question of potential student investment in cultural representations is take up by the volume's section on "Desire, Audience, and the Politics of Cultural Memory," which includes the most engaging essays of the collections: Dyson's on Michael Jordan, Becker's on contemporary art and audience, bell hooks' inspiring piece "Eros, Eroticism, and the Pedagogical Process," and Roger Simon's application of a "pedagogy of countercommemoration" to the Columbus Quincentenary.

One of the problems with many of the essays in Between Borders that treat the influence of mass culture and mass media-Dyson's, Collins', and Giroux's, especially - is the lack of a clear sense of how (in what manner and with what effect) these vehicles of representation shape potential students. Are we to assume, for instance, that when white students watch Grand Canyon or listen to Pat Buchanan they do so uncritically, ${ }^{2}$ and necessarily internalize a homogeneous whiteness? Do students of color uniformly take up Michael Jordan as a "cultural pedagogue" and "the symbolic carrier of racial and cultural desires"? And then what is the relationship between a pedagogue and an icon or an old-fashioned role model? Again, the waters surrounding practical pedagogy tend to get muddied here.

In the final section of his essay, Giroux does tie these theoretical questions to a practical pedagogy. Bringing a pedagogy of representation into the classroom, claims Giroux, would have two principle advantages. Cultural workers (teachers) would enable students to recover and rewrite the "hidden histories" of their identities by giving them the "tools to challenge any notion of subjectivity" which treats history as "unchanging, monolithic, or static" (50). Second, Giroux's pedagogy would help students challenge racist, sexist, and colonist representations by paying attention to "how the incorporation of the everyday is mobilized within the text of mass culture" to produce particular power relations (50). Alluding to his earlier reading of Grand Canyon, Giroux asserts:

I am particularly concerned here about a representational pedagogy that makes whiteness visible as an ethnic category. About making white students understand 
how their own identities are beyond neither ethnicity, history, privilege, nor struggle. Cultural difference... must be taken up as a relational issue and not as one that serves to isolate and mark particular groups. This has important pedagogical implications. (51)

Because I am often in the position of teaching courses which emphasize "diversity" to students who are overwhelmingly white and middle class, I find this particular suggestion appealing. Like the teachers whose experience Giroux cites in "Living Dangerously," I've found that my white students often believe that ethnicity itself is something they lack, something marginal and other. Greater attention to how American "whiteness" is fractured along lines of gender, class, religion, region, and ethnic background would help white students to feel more a part of and invest themselves in the America's multiculturalism.

Few of the essays in this collection go as far as Giroux's either in putting forth specific pedagogical suggestions or in providing the sort of comprehensive theoretical plan of his representational pedagogy. Still, the volume is a challenging and thoughtful attempt to unite cultural studies with pedagogy in order to engage pressing educational and cultural issues that too many politicians, school administrators, and educators would rather ignore.

\section{Notes}

'Steve Mathews, "An Interview with Jean Franco," Iowa Journal of Cultural Studies 12 (1993): 156-169.

${ }^{2}$ Several essays treat Pat Buchanan's 1992 Republican Convention speech as the epitome of the New Right's advances into the cultural arena, an interesting and even prescient choice in light of the relative success of Buchanan's 1996 Presidential bid. 